\title{
Usefulness of gastric submucosal dissection depth to evaluate skill acquirement in short term training courses in ESD: an experimental study
}

\author{
Kendi YAMAZAKI ${ }^{1}$, Eduardo Guimarães Hourneaux de MOURA ${ }^{1}$, Mariana Matera VERAS ${ }^{2}$, \\ Luiz Henrique MESTIERI ${ }^{1}$ and Paulo SAKAI ${ }^{1}$
}

Received 4/2/2018

Accepted 22/6/2018

\begin{abstract}
Background - Endoscopic submucosal dissection (ESD) is a complex endoscopic procedure, with high rates of adverse events and technical difficulties. To overcome that problem, many training centers published the importance of animal models for skill acquirement in ESD. However, no study has used the submucosal dissection depth (DSUB) as a parameter to evaluate the learning curve in ESD, which might be a relevant factor since an optimal resection plane is important to achieve a curative resection and avoid intraoperative complications. Objective - This study aimed to assess ESD skill acquirement after short-term training sessions by evaluating the submucosal dissection depth (DSUB) and the association with adverse events. Methods - This experimental study included 25 experienced endoscopists in therapeuthic procedures ( $>5$ years) and 75 specimens resected by ESD (three resections / endoscopist). Learning parameters (resection time, size, en bloc resection rate, bleeding, perforation and submucosal dissection depth) were prospectively evaluated. The percentages of DSUB of all specimens resected were calculated. Results - All specimens were resected from the gastric body $(\mathrm{n}=75)$. The mean size of the resected specimens was $23.97 \pm 7.2 \mathrm{~mm}$. The number of adverse events, including bleeding, perforation, and death, were $17(22.67 \%), 3(4 \%)$, and 0 cases, respectively. The average mean time by the third dissection decreased from $28.44 \pm 9.73$ to $18.72 \pm 8.81$ $\min (P<0.001)$. The proportion of DSUB in the bleeding and non-bleeding group were respectively $37.97 \% \pm 21.13 \%$ and $68.66 \% \pm 23.99 \%$, indicating a significant association between DSUB and bleeding incidence $(P<0.001)$. The ROC curve analysis indicated a cut-off point of $61 \%$ (sensitivity, $64 \%$; specificity, $94 \%$ ) of submucosal dissection depth associated with bleeding. Therefore, when ESD was performed at a depth of $>61 \%$ of the submucosal layer, the risk for bleeding during the procedure decreased (PPV, 0.97; 95\% CI, 0.85-0.99). Conclusion - Improvement in the learning curve in ESD and a better cognitive ability were seen by the third dissection in these short term training courses. And a significant association between DSUB and the risk of bleeding.

HEADINGS - Endoscopic mucosal resection, education. Gastric mucosa. Gastroscopy. Treatment outcome.
\end{abstract}

\section{INTRODUCTION}

Endoscopic submucosal dissection (ESD) has been gaining acceptance in several countries ${ }^{(1-3)}$; however, the difficulty level combined with adverse events, such as bleeding and perforation, limit the use of ESD by endoscopists. The risk of adverse events depends on the experience and expertise of the operator, patient comorbidities (e.g., hypertension, diabetes, bleeding disorders, anticoagulant use), and factors intrinsic to lesions such as the location, size, and degree of submucosal invasion ${ }^{(4)}$.

In Japan, it is believed that beginners of ESD can achieve acceptable expertise levels after performing 20 to 30 resections $^{(5-12)}$. This teaching method is difficult to replicate in western countries because of the low incidence of gastric cancer, which limits the learning curve in ESD.

Considering the importance of learning ESD, most western countries proposed ESD training in experimental animals before performing it in humans ${ }^{(5)}$.
In several studies on ESD training that used in vivo and ex vivo animal models, the assessment of skill acquisition is based on the analysis of variables such as resection time, en bloc resection, complete lateral margin resection, bleeding and perforation ${ }^{(5-11)}$.

The analysis of these parameters is essential but does not include the resection depth of the gastric submucosa. This is an important factor because endoscopic treatment of EGC is only acceptable when the lesion extends below $500 \mu \mathrm{m}$ into the submucosa. [i.e., to the first submucosal (SM1) layer]. Therefore, the resection depth should reach at least the SM1 layer ${ }^{(12)}$.

This concept should be considered to achieve an optimal resection plane and consequently, curative resection.

In addition, there may be an association between the submucosal dissection depth (DSUB) and the risk for bleeding ${ }^{(13,14)}$. This raises the concern about whether DSUB is an important factor to be analyzed during ESD training in live porcine models.

The primary objective is to evaluate the knowledge gain on short-term training courses in ESD, by using DSUB and other 
known parameters such as resection time, volume of submucosal injection, en bloc resection rate, specimen size, and adverse events (bleeding and perforation).

The secondary objective is to evaluate the association between DSUB and the risk of adverse events (bleeding and perforation).

\section{METHODS}

This experimental study was conducted between July 2011 and July 2013 at the Gastrointestinal Endoscopy Unit (Gastroenterology Department), Experimental Surgery Division and Department of Pathology (LIM05) of the University of São Paulo Medical School.

\section{Selection of participants}

A questionnaire was given to all physician participants to assess the years of medical practice; specialty; years of endoscopy experience; number of endoscopies, colonoscopies and endoscopic retrograde cholangiopancreatography (ERCPs) examinations performed/year and previous experience of ESD. Voluntary informed consent was signed by all participants.

\section{Inclusion criteria}

- Medical professional with a specialization in endoscopy.

- Minimum experience of 5 years in endoscopy.

- Experience in advanced therapeutic endoscopic techniques.

- No previous experience in ESD.

\section{Exclusion criteria}

- Execution of ESD in different parts of the gastric body.

- Use of a technique different from the standard technique

- Failure to fill out the questionnaire

- Specimens that were missing, unlabeled or defective

\section{Endoscopic submucosal dissection training technique in live porcine models}

Gastric lesions were simulated in a live porcine model by aspirating the gastric mucosa using a distal attachment cap (Olympus D-201-10704), which was inserted into the tip of the endoscope. For a uniform analysis, all lesions were created at the gastric body.

The technique, standardized by Hosokawa et al. (15) begins with circumferential marking of the lesion (FIGURE 1A) using a needle knife (Olympus, KD-620LR) at a distance of approximately 2 to 3 $\mathrm{mm}$ outside the lesion. This circumferential marking was performed using electrocautery in coagulation mode (soft coagulation, $30 \mathrm{~W}$ ).

A solution containing 20\% mannitol and indigo carmine was injected into the submucosa using a 23-gauge sclerosis catheter (Olympus NM-200L-0423) to form a submucosal cushion and enable appropriate elevation of the lesion (FIGURE 1B).

Using a needle knife and electrocautery (Endocut, $40 \mathrm{~W}$ ), a pre-incision was made approximately 1 to $2 \mathrm{~mm}$ outside the marked area. An IT-Knife (KD-611L) was inserted into the pre-incision so that the submucosal dissection outside the demarcated area would encircle the entire lesion (FIGURES 1C, 1D, 1E). Submucosal dissection was performed until the lesion was completely resected (FIGURES 1F,1G,1H).

The resected specimen was removed using a foreign body forceps (Olympus GF-47L-1), stretched and fixed with pins on a Styrofoam plate, and subsequently transferred to a container with $10 \%$ formalin solution. The specimens were labeled regarding the gastric region resected, operator name, and the number of the operating table. Specimens that were missing, unlabeled, or defective were not eligible for the study. Pathologists were blinded to any information regarding the resected specimens or the outcomes during ESD training.

In this study, intraprocedural bleeding is defined as any visible bleeding episode that develops during the submucosal dissection. In the event of intraprocedural bleeding, the methods of choice used for hemostasis were endoscopic clips (Olympus HX-610-090 and 135), electrocautery, or injection methods. The injection method of choice was adrenaline combined with saline solution of 1:10,000 or 1:20,000. Postprocedural bleeding was not assessed since the porcine models would be euthanized soon after the procedure. In cases of perforation, the treatment involved the use of metal clips (Olympus HX-135 and 610-090).

\section{Laparotomy for gastric wall samples}

After endoscopic resections were done, laparotomy was conducted to obtain a transmural sample of the gastric wall (greater curvature of the body) of each live pig used in the study as a reference (control group) to estimate the depth of submucosal resection by ESD.

Histological examination and measurement of the gastric layer

Histopathological examination of the resected specimens was performed using hematoxylin and eosin staining.

The thickness of each gastric layer was measured using stereological techniques. Stereology is a set of methods used to quantify morphological structures enabling the interpretation of solid structures using two-dimensional images (e.g., tissue sections, radiological images, and ultrasound images).

Stereology has some advantages over traditional measurement methods. Conventional methods measure two-dimensional images, such as the direct measurement of a histological section in micrometers, using a microscope. In contrast, stereological techniques enable the estimation of volume, density, area, number of cells, and other data in a three-dimensional format using twodimensional information of the target object. Therefore, several statistical and geometrical analyses may be performed (e.g., sample size, uniform randomization of the sectioned areas, and isotropy) while maintaining statistical rigor. The advantage of stereological
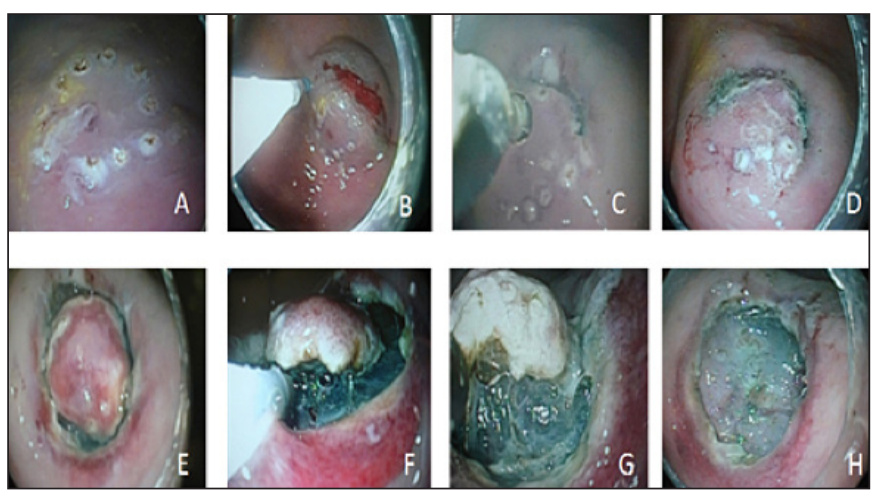

FIGURE 1. Schematic representation of the endoscopic submucosal dissection (ESD) technique. A) Marking of the lesion; B) Submucosal injection; C, D, E) Pre-cut and circunferencial incision; F, G) Submucosal dissection; H) Complete resection. [Source: Gastrointestinal Endoscopy Unit University of São Paulo Medical School (photos) and Hosokawa et al. ${ }^{15}$ ]. 
studies is the production of numerical (objective) results, with good reproducibility and rapid assessment, in addition to the low cost of the equipment used ${ }^{(16)}$.

Nyengaard et al. ${ }^{(17)}$ described the applicability of these methods in estimating the number of cells, total volume, and average length of stomach in rats using histological images of the gastric wall.

Stereological techniques are often used in experimental neuroscience studies, particularly those of brain areas that are inaccessible by other methods, for the accurate quantification of volume, area, and spatial distribution of neural cells ${ }^{(18)}$, making this method practical and feasible for measuring the area of gastric layers.

In this study, the measurement of the gastric layer area was performed by evaluating the area percentage $\left(\mathrm{Av}_{\text {comp }}\right)$ of each compartment using a point counting method ${ }^{19}$. The tissue sections with the deepest dissection depth of each specimen were chosen for this analysis $\left(\Sigma \mathrm{P}_{\text {comp }}\right)$ and compared with gastric transmural samples $\left(\Sigma \mathrm{P}_{\mathrm{Tot}}\right)$ obtained on the same area where ESD was performed. For this purpose, photomicrographs of tissue section were created, with a magnification of $4 \times$, and a point test system was superimposed on the images. The incident points on each of the compartments of interest were differentially counted, and $\mathrm{Av}_{\text {comp }}{ }^{(19,20)}$ was calculated using the following formula ${ }^{(1)}$ :

\begin{tabular}{|l|l|}
\hline $\mathrm{Av}_{\text {comp }}=\Sigma \mathrm{P}_{\text {comp }} / \Sigma \mathrm{P}_{\text {Tot }}$ & (1) \\
\hline Where, $\Sigma \mathrm{P}_{\text {comp }}$ is the sum of the number of incident points & \\
in one compartment. & \\
$\Sigma \mathrm{P}_{\text {Tot }}$ is the sum of the number of incident points in all \\
compartments of the gastric wall.
\end{tabular}

The software program Image $\mathbf{J}$ was used for all counts and measurements. Each counter type is shown in the left column and corresponds to one of the layers evaluated (FIGURE 2).

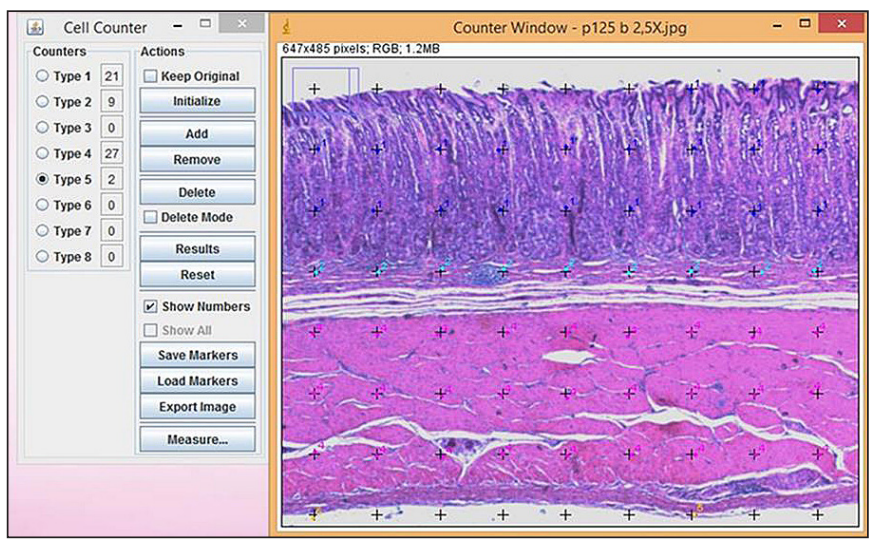

FIGURE 2. Representation of counting the incident points using Image J [Source: Experimental Air Pollution Laboratory, Department of Pathology (LIM 05) FMUSP].

\section{Initial sample}

Twenty five endoscopists were eligible for the study and they were divided into eight groups (3-4 participants/group). Each group had two to three live porcine models available for a 1-day training session. Each endoscopist performed at least three resections. Seventeen live porcine models were used for the study. A total of 92 specimens (17 operated transmural sample and 75 resected by ESD) eligible for the study (FIGURE 3).

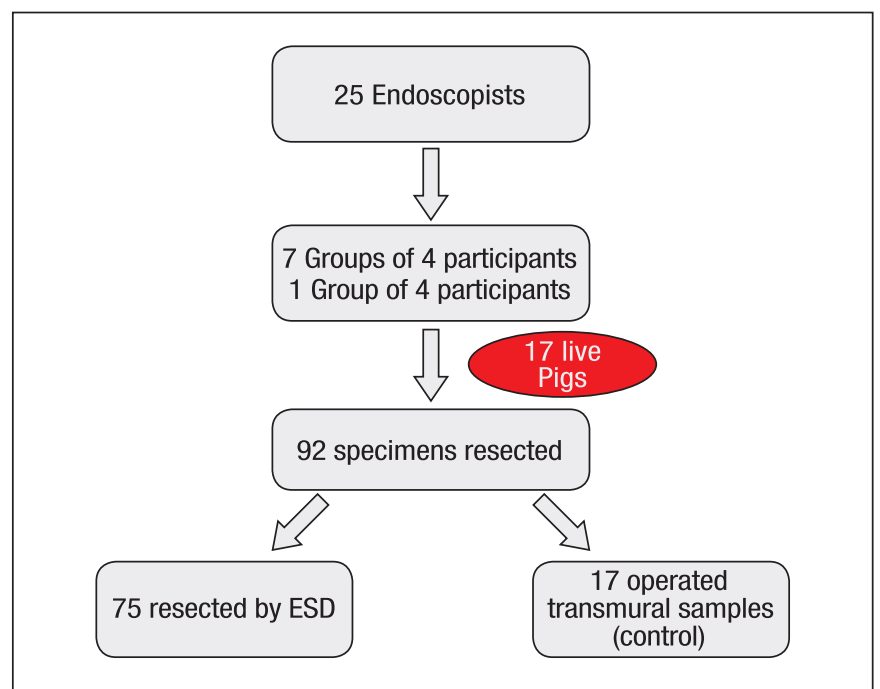

FIGURE 3. Schematic representation of number of participants, resected specimens and live porcine models.

\section{Study flowchart}

The study was divided into two phases, corresponding to different assessment periods. The objective of phase 1 was to evaluate training in dissections performed by each participant during ESD. Phase 2 included the histological analysis of the resected specimens (FIGURE 4).

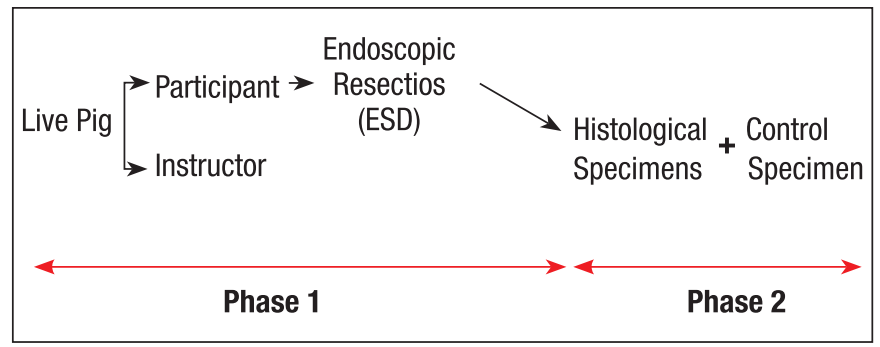

FIGURE 4. Schematic representation of the study phases.

\section{ESD training evaluation (phase 1)}

The day before the endoscopic dissections, all participants received a 4-hour lecture on the key points of ESD. The lecture was given by an experienced endoscopist (>300 cases of gastric ESD). Videos were also presented to demonstrate ESD cases previously performed by the lecturer.

The lecturer gave a practical demonstration of how to execute endoscopic dissection using a live porcine model. Subsequently, each subject performed a minimum of three endoscopic resections. All procedures were performed at the gastric body and under the supervision of experts.

Each trainee performed all resections on the same day. After all participants of each group finished the first resection, they would start the second resection, and so on. None of them were instructed to perform deeper resections.

The variables of interest collected after each resection are as follow: resection time ( $\triangle \mathrm{TR}$ : $\mathrm{min}$ ) starting from the marking of the lesion to the end of submucosal dissection; volume of submucosal injection $(\mathrm{mL})$; size of the resected specimen $(\mathrm{mm})$; location of the lesion; and incidence of bleeding, perforation and death. 
These variables were defined according to current medical literature as criteria of technical proficiency ${ }^{(5,6,11,20-27)}$. The variables were collected by an independent observer after each dissection: first (D1), second (D2), and third (D3). Thus, the outcome of phase 1 was to evaluate ESD training in a live porcine model using the aforementioned technical criteria.

\section{Submucosal dissection depth (phase 2)}

The thickness of the gastric wall varies among live pigs. Therefore, to enable the assessment of endoscopic resection depth, gastric transmural samples were collected (laparotomy) in the same area where endoscopic resections were performed. The submucosal compartments of these samples (control specimen) were used as a parameter to evaluate how deep the endoscopic resection has been taken i.e, submucosal dissection depth (FIGURE 5). After the resection, the specimen were fixed and forwarded to the Pathology Department with no further information about the endoscopic dissection outcomes on phase I and II or any other information about the resected specimens on D1, D2 and D3. The pathologists were instructed to analyse and measure the submucosal dissection depth only.

The primary outcome assessed in this phase was to evaluate the association between DSUB and variables collected in phase 1.

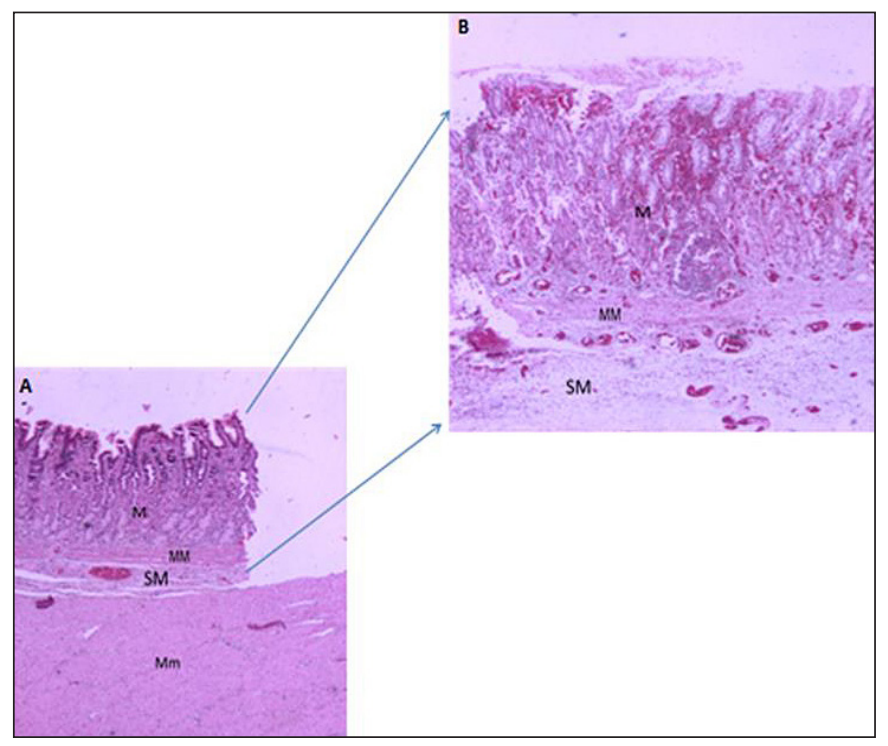

FIGURE 5. Photomicrographs of cross-sections of the gastric wall of pigs after resection. A) Transmural specimen resected by surgery (control specimen). B) Specimen endoscopically resected using ESD in the same pig. Identification of gastric compartments (layers). M: mucosa; MM: muscularis mucosa; SM: submucosa; Mm: muscle [Source: Experimental Air Pollution Laboratory, Department of Pathology (LIM 05) FMUSP].

\section{Ethical considerations, anesthesia, and euthanasia}

The study was approved by the Ethics Committee on Animal Use and the Research Ethics Committee of the University of Sao Paulo Medical School. Male and female domestic pigs of a hybrid breed (Landrace $\times$ Pietran $\times$ Duroc), with an average weight of $20 \pm 2 \mathrm{~kg}$, were used in this study and previously subjected to a veterinary evaluation to rule out any obvious clinical infectious diseases. The procedure was performed under general anesthesia.
During the procedure, temperature, oxygen saturation, and heart rate were monitored $(28,29)$.

After the endoscopic procedure, the animals were euthanized by a method recommended by the Federation of Laboratory Animal Science Associations and Guidelines on Euthanasia( ${ }^{(29,30)}$.

\section{Statistical analysis}

Quantitative variables were presented as mean \pm standard deviation; and all qualitative variables were presented as frequencies $(\%)$ with $95 \%$ confidence interval (CI) calculated. Median values were given for outliers.

Non-parametric analysis of variance for repeated measures was used to evaluate the effect of repeating dissections over time ${ }^{(31)}$. Measurements assessed at baseline (D1) and in the final dissection (D3) were compared using the non-parametric Dunnett test ${ }^{(32)}$.

The association among the factors involved in complications was evaluated using the Mann-Whitney test for quantitative variables and Fisher's exact test for qualitative variables.

Finally, based on the submucosal dissection depth receiver operation characteristic (ROC) curve analysis was performed to determine the optimal depth necessary to reduce the risk of bleeding, calculating the area under the ROC curve (AUC). A cut-off point was estimated using the Youden- Index to maximize the sensitivity and specificity desirable to create the test (maximum= sensitivity + specificity-1), so that an "optimal cut-off" point with a maximal sensitivity and specificity could be determined on the ROC curve. Subsequently, 95\% CIs were calculated for all diagnostic measures: AUC, sensitivity, specificity, and positive and negative predictive values.

$P$ values of $<0.05$ were considered statistically significant. All statistical analyses were performed using the software program $\mathrm{R}$ version $3.1 .2^{(33)}$.

\section{RESULTS}

A total of 92 specimens (75 ESDs and 17 control specimens) were resected and included in the study. The mean size of the resected specimens was $23.97 \pm 7.2 \mathrm{~mm}$.

Specimens were resected from the greater curvature and anterior wall of the gastric body. The resection mean time was $23.97 \pm 11.74$ minutes.

In addition, $94.67 \%$ en bloc resections were performed, and specimen fragmentation occurred in four $(5.33 \%)$ cases.

The adverse events were divided into two types: intraprocedural bleeding [17 $(22.67 \%)$ cases] and perforation [3 (4\%) cases]. There were no cases of death.

\section{Assessment of ESD learning \\ - Trend analysis}

The trend analysis of variables enabled the observation of the effect of repeating the dissections (from D1 to D3). Interestingly, deepening of the submucosal resection was seen during the study but resection time and bleeding rate were the most significant trend. (TABLE 1).

\section{Variables of interest versus adverse events - Bleeding}

There were 17 cases $(22.67 \%)$ of bleeding among the 75 resections. The association between the variables of interest and the presence or absence of bleeding was analyzed (TABLE 2). 
TABLE 1 . Values of the variables analyzed in D1, D2, and D3.

\begin{tabular}{|c|c|c|c|c|}
\hline & D1 $(n=25)$ & D2 $(n=25)$ & D3 $(n=25)$ & $P$ value \\
\hline Size $(\mathrm{mm}) *$ & $22.68 \pm 6.89$ & $22.6 \pm 7.33$ & $26.64 \pm 6.9$ & 0.17 \\
\hline Bleeding $(\%)^{* *}$ & $\begin{array}{c}8(32 \%) \\
(17.18-51.78)\end{array}$ & $\begin{array}{c}5(20 \%) \\
(8.56-39.71)\end{array}$ & $\begin{array}{c}4(16 \%) \\
(5.95-35.43)\end{array}$ & 0.047 \\
\hline Perforation $(\%)^{* *}$ & $0(0 \%)$ & $0(0 \%)$ & $\begin{array}{c}3(12 \%) \\
(3.49-30.99)\end{array}$ & 0.07 \\
\hline Fragmented specimens $(\%)^{* *}$ & $\begin{array}{c}1(4 \%) \\
(0-21.43)\end{array}$ & $\begin{array}{c}1(4 \%) \\
(0-21.43)\end{array}$ & $\begin{array}{c}2(8 \%) \\
(1.24-26.34)\end{array}$ & 0.77 \\
\hline Submucosal dissection depth $(\%)^{*}$ & $53.5 \pm 23.76$ & $61.8 \pm 26.47$ & $69.82 \pm 27.86$ & 0.073 \\
\hline
\end{tabular}

*Values are expressed as mean \pm standard deviation. **Values with $95 \%$ confidence interval.

TABLE 2. Association between the variables of interest and bleeding.

\begin{tabular}{lccc}
\hline & $\begin{array}{c}\text { Bleeding } \\
(\mathrm{n}=17)\end{array}$ & $\begin{array}{c}\text { No Bleeding } \\
(\mathrm{n}=58)\end{array}$ & $P$ \\
\hline Resection time $(\mathrm{min}) *$ & $25.71 \pm 10.82$ & $23.47 \pm 12.04$ & 0.339 \\
Submucosal injection $(\mathrm{mL}) *$ & $22.29 \pm 13.28$ & $23.69 \pm 14.18$ & 0.704 \\
Fragmented specimens (\%) & 0 & 6.9 & 1.0 \\
$\begin{array}{l}\text { Em bloc resected } \\
\text { specimens }(\%)\end{array}$ & 100 & 93.1 & 1.0 \\
\hline
\end{tabular}

*Values are expressed as mean \pm standard deviation (SD).

Factors, such as resection time $(P=0.339)$, volume of submucosal injection to lift the lesion $(P=0.704)$, and specimen fragmentation during resection $(P=1)$ did not influence the risk of intraoperative bleeding (TABLE 2).

\section{- Perforation}

There were three $(4 \%)$ cases of perforation among the 75 resections. These cases occurred in D3. In addition, there was no significant association among resection time $(P=0.344)$, volume of the submucosal injection $(P=0.223)$, specimen fragmentation $(P=0.154)$, and perforation risk during resection (TABLE 3$)$.

TABLE 3. Association between the variables of interest and perforation.

\begin{tabular}{lccc}
\hline & $\begin{array}{c}\text { Perforation } \\
(\mathbf{n}=3)\end{array}$ & $\begin{array}{c}\text { Non perforation } \\
(\mathbf{n}=72)\end{array}$ & $P$ \\
\hline Resection time (min)* & $\begin{array}{c}17.33 \pm \\
2.89\end{array}$ & $24.25 \pm 11.9$ & 0.344 \\
& & & \\
Submucosal injection $(\mathrm{mL}) *$ & $15 \pm 2.65$ & $23.72 \pm 14.08$ & 0.223 \\
Fragmented specimens (\%) & 33.33 & 4.17 & 0.154 \\
$\begin{array}{l}\text { En bloc resected } \\
\text { specimens (\%) }\end{array}$ & 66.67 & 95.83 & 0.154 \\
\hline
\end{tabular}

*Values are expressed as mean \pm standard deviation (SD).

\section{- Submucosal dissection depth}

Histological analysis of the submucosa enabled the measurement of $\mathrm{D}_{\text {SUB }}$ and the association between $\mathrm{D}_{\text {SUB }}$ and adverse events. No significant results in the comparative analysis between perforation and the depth of submucosal dissection were seen $(P=0.324)$ due to few cases of perforation $(n=3)$.

Other variables such as resection time and submucosal injection volume were compared with $\mathrm{D}_{\mathrm{SUB}}$, showing a non-associable trend between these factors.

On the other hand, significant association between $\mathrm{D}_{\text {SUB }}$ and bleeding risk during the procedure was seen $(P<0.001)$. The $\mathrm{D}_{\text {SUB }}$ mean value in the bleeding group was $37.97 \% \pm 21.13 \%$ and the non-bleeding group was $68.66 \% \pm 23.99 \%$.

Few outliers were seen, so calculating the median value was preferable where submucosal dissection depth were significantly different between the bleeding and non-bleeding groups, corresponding to $27.95 \%$ and $73.11 \%$, respectively (FIGURE 6).

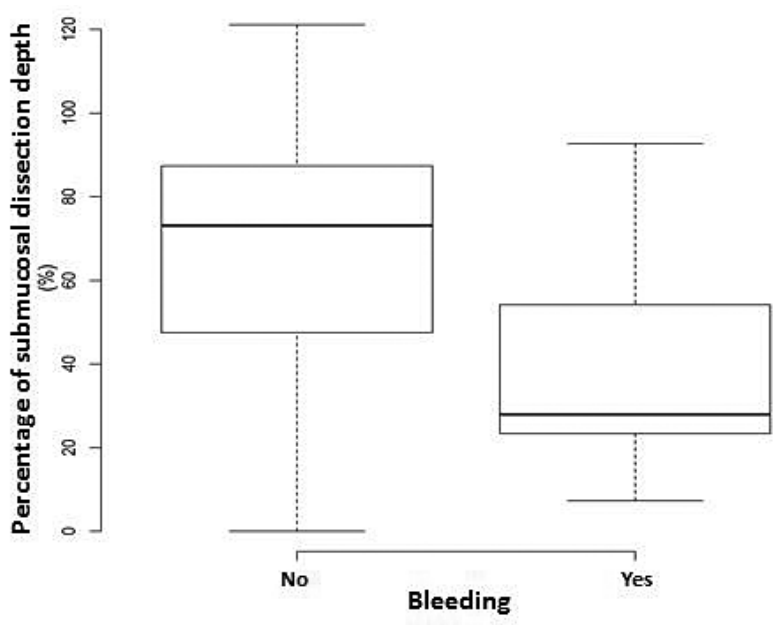

FIGURE 6. Sample distribution between bleeding and non-bleeding group. 


\section{- ROC curve analysis}

Based on the submucosal dissection depth, ROC curve analysis was performed to determine the optimal depth necessary to reduce the risk of intraprocedural bleeding and the AUC was calculated. According to this analysis, the point with the largest AUC was defined as the point having the greatest association with bleeding. Optimal cutoff points were determined on the basis of maximum values of the Youden Index, which indicates the minimum distance from the upper left corner to the point of the ROC curve (FIGURE 7).

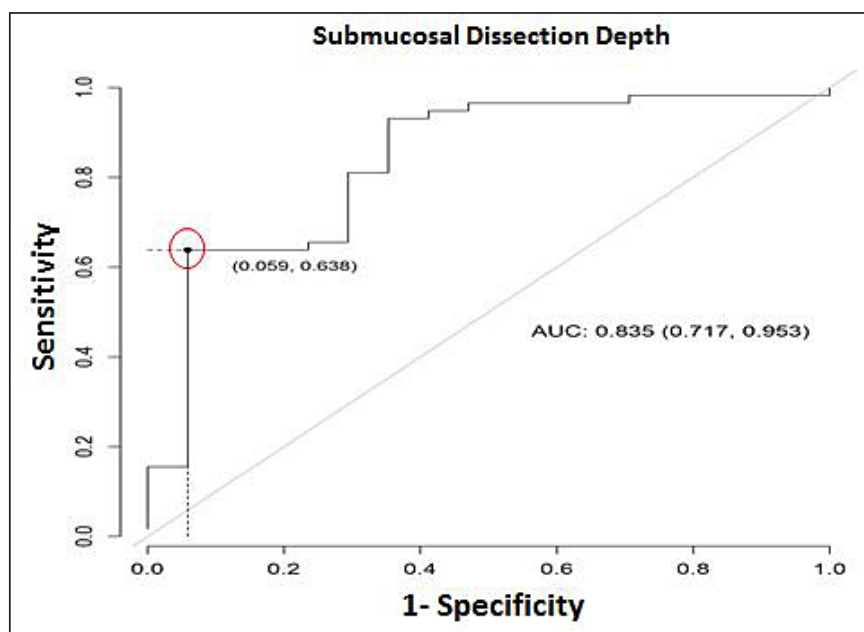

FIGURE 7. ROC curve analysis of bleeding development after endoscopic submucosal dissection. The resulting cutoff point of the submucosal dissection depth for bleeding was $61 \%$ (specificity, 94\%; sensitivity, 64\%). Sensitivity is shown in the Y-axis, and specificity is shown in the $\mathrm{X}$-axis.

The results of estimating the cutoff point (TABLE 4) with strong association between $\mathrm{D}_{\mathrm{SUB}}$ and bleeding was $61 \%$ (sensitivity, $64 \%$; specificity, $94 \%$ ). Therefore, when $\mathrm{D}_{\text {SUB }}$ was larger than $61 \%$ of the submucosal area, there was a strong probability of the absence of bleeding during the procedure (PPV, 0.97; 95\% CI, 0.85-0.99). Consequently, the risk for bleeding was high when the submucosal dissection depth was less than $61 \%$ (NPV, $0.43 ; 95 \%$ CI, $0.30-0.97$ ).

TABLE 4. Results in estimating the cutoff point based on the Youden-Index.

\begin{tabular}{lccc}
\hline & \multicolumn{3}{c}{ Submuc. dissect. depth (DSUB) } \\
\cline { 2 - 4 } & ESTIMATE & \multicolumn{2}{c}{$95 \%$ CI } \\
\hline CUTOFF & 61.03 & NA & NA \\
Se & 0.64 & 0.5 & 0.76 \\
Sp & 0.94 & 0.71 & 1 \\
PPV & 0.97 & 0.85 & 0.99 \\
NPV & 0.43 & 0.3 & 0.97 \\
DLR positive & 10.84 & 1.6 & 73.33 \\
DLR negative & 0.38 & 0.27 & 0.55 \\
FP & 1 & NA & NA \\
FN & 21 & NA & NA \\
\hline
\end{tabular}

Se: sensitivity; Sp: specificity; PPV: positive predictive value; NPV: negative predictive value; DLR positive: positive diagnostic likelihood ratio; DLR negative: negative diagnostic likelihood ratio; FP: false positive; FN: false negative.

\section{DISCUSSION}

ESD was developed in Japan in the $1990 \mathrm{~s}^{(16)}$. This technique quickly revolutionized the treatment of early cancer by enabling the resection of lesions larger than $2 \mathrm{~cm}$, with excellent oncological control.

However, a minimum learning curve is needed to achieve a safe resection and remain within the recommended oncological standards ${ }^{(6,23)}$. It is expected that most elaborate learning programs are from Japan, where the training algorithm is divided into two primary stages: theoretical preparation and practical training ${ }^{(23,25)}$.

In Japan, practical training does not usually involve the use of simulators. The procedure is performed in humans, by endoscopists under direct supervision of an expert ${ }^{(24)}$.

Unfortunately, the extensive experience of ESD in Japan cannot be replicated in western countries, which limits the opportunities for learning the technique. Simulators are valuable tools because they enable the development of the necessary cognitive ability and diminish the period to achieve an optimal learning curve ${ }^{(8,21,23,34)}$.

In complex endoscopic procedures such as ESD, it is necessary to select a simulator capable of reproducing a reliable tactile sensation that is similar to a real procedure and providing an opportunity to treat potential complications such as perforation and bleeding ${ }^{(23)}$.

In this scenario, live pigs better simulates the human stomach because of anatomical similarities, particularly with regard to the gastric wall layers, vascularization, gastric secretions, peristaltic movements, and the possibility of bleeding ${ }^{(35-38)}$.

The main disadvantages of using live animals are the logistics for animal care, high cost, and ethical considerations ${ }^{(39)}$.

At present, in countries with limited experience in ESD, simulators are the only option as a starting point for ESD training $(5,40,41)$.

Therefore, different algorithms have been proposed for training, which seeks to integrate the accumulation of theoretical knowledge (diagnosis, indications, complications, and accessories), training under expert supervision, and visits to specialized centers in Japan ${ }^{(22)}$.

In many reports the proficiency indicators for ESD training are resection time, en bloc resection rate, and safety (low incidence of adverse events $)^{(5,13,21-24)}$. In this study we used a short-term training course in ESD so the number of procedures per student were fewer than other published papers ${ }^{(8,10)}$, however it was possible to observe a progressive improvement in the resection time $(P<0.001)$ and reduction in the bleeding rate $(P=0.047)$, which do not differ from those in the literature ${ }^{(5-13,21-24)}$

In addition, histological analysis of the specimens indicated an increase in the submucosal dissection depth $(P=0.073)$, demonstrating a trend toward deepening of the dissection plane.

What really differs from other studies is that all participants were experienced endoscopists who already had expertise in other therapeutic procedures which was a determining factor for a good performance, even after only three resections.

However, there were few cases of perforation $(n=3)$, all of them on the third dissection which might lead to the assumption that participants were less cautious during ESD due to the selfconfidence gained during the training.

Berr et al. ${ }^{(42)}$ conducted a case series study in which they demonstrated that an endoscopist with previous experience on interventional procedures, after a theoretical learning period in Japan, succeeded in conducting ESD in his home country without the guidance of an expert, with a perforation rate of $14 \%$ and a bleeding rate of $4 \%{ }^{(42)}$, which are not unacceptably high, considering that 
complication rates in Japan varies between, 3\% to $7 \%$ for bleeding and $1 \%$ to $12 \%$ for perforation ${ }^{(43,44)}$. Thus, perhaps, the endoscopists experience in therapeutic procedures might have more relevance than the number of resections to achieve an ideal learning curve.

Moreover, resection depth has never been determined to be an important variable to be analyzed during ESD training in animal models. This factor is important because of two principles. a) The Japanese Gastric Cancer Association(27) reported that one of the criteria of curability is when the tumor does not penetrate the first submucosa layer or reaches a depth of up to $500 \mu \mathrm{m}$ from the SM1, which means that when endoscopic resection is indicated, the endoscopist should go deep enough to include this small portion of the submucosa. b) The gastric vasculature responsible for bleeding during ESD is mostly from the ramified vascular network located in the superficial submucosal layer ${ }^{(45)}$, which suggests that the best strategy to prevent intraprocedural bleeding is to maintain the appropriate dissection depth to reach the avascular stratum located just above the muscle layer where fewer but larger vessels arise, enabling the easy identification to perform cauterization ${ }^{(13)}$.

Toyonaga et al. ${ }^{(45)}$ observed that the ideal dissection plane was closest to the muscle layer because of the presence of fewer and larger caliber vessels, making their identification easier and reducing the risk for bleeding (FIGURE 8).
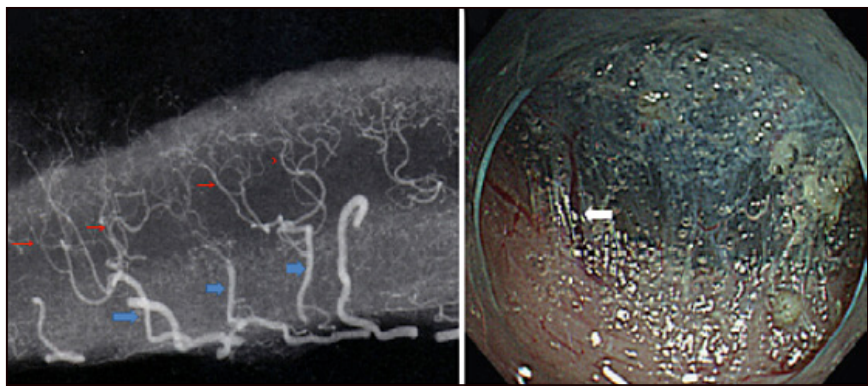

FIGURE 8. Vasculature of the gastric submucosal layer. A) Contrast photomicrograph of the submucosal vessels of the deepest submucosal layer (blue arrow) and its branches located in the superficial submucosal layer (red arrow). B) Image obtained during ESD, showing larger caliber vessel (white arrow) near the muscle layer [Source: Takashi Toyonaga, Department of Endoscopy, Kobe University Hospital]

However, there are no clinical studies to support this theory. Association studies between risk of intraprocedural bleeding and the depth of submucosal dissection would be difficult to conduct, primarily because of the clinical variability among patients, other risk factors (hypertension, coagulopathy, cirrhosis, diabetes, anticoagulant use), and factors intrinsic to the lesion (size, location, submucosal invasion, and recurrence) $)^{(4,46,47)}$. These confounding factors are eliminated using experimental animals.
The $\mathrm{D}_{\mathrm{SuB}} \mathrm{s}$ of the specimens resected by ESD were calculated using stereological methods based on point counting and estimated in percentage of the total gastric wall (transmural gastric sample).

As a result, we could observe that the number of cases of intraprocedural bleeding significantly decreased when endoscopic resections were performed at deeper levels $(P<0.001)$.

This result corroborates the hypothesis held by some authors, concerning the importance of finding the ideal submucosal dissection plane for better visualization of vessels and consequently, reducing the risk for bleeding $(13,45)$.

Based on the Youden-Index a cut-off point was estimated to reduce the risk of bleeding.

The resulting cut-off point was $61 \%$ (sensitivity, 64\%; specificity, $94 \%$ ), given that sensitivity was defined as the probability that the submucosal resection rate was above the cut-off point in cases in which bleeding did not occur and specificity was defined as the probability that the submucosal resection rate was below the cut-off point in cases in which bleeding occurred. The fact that bleeding could harm the patient, favors the use of a cut-off point with greater specificity to avoid bleeding (true negatives).

Therefore, when the submucosal resection rate was higher than $61 \%$, there was a strong likelihood that bleeding would not occur during the procedure (PPV, 0.97; 95\% CI, 0.85-0.99), and the risk for bleeding increased when resection was below $61 \%$ (NPV, 0.43 ; 95\% CI, 0.30-0.97).

This statistical inference indicates that the evaluation of endoscopic resection depth in conjunction with other variables (resection time, en bloc resection rate, size and adverse events) might be important in the teaching process during ESD training in live porcine models. Other factors contribute to the bleeding risk in ESD, but we were able to show the importance of measuring the submucosal dissection depth during ESD training on animal models. We used the $\mathrm{D}_{\mathrm{SUB}}$, not as the only but one of the variables to achieve an ideal learning curve in ESD.

\section{CONCLUSION}

The short-term training model allowed cognitive improvement from D3, with shorter resection time, reduced bleeding rate and deeper submucosal resection rates.

There was a significant association between submucosal dissection depth and the bleeding incidence during ESD training.

\section{Authors' contribution}

Yamazaki K, Mestieri LH, Veras MM, Sakai P and Moura EGH: protocol/project development, data collection and management. All authors contributed significantly to the analysis, literature review and writing of the final submitted version, and share responsibility for the contents of this paper. 
Yamazaki K, Moura EGH, Veras MM, Mestieri LH, Sakai P. A aplicação da profundidade de dissecção da submucosa gástrica na avaliação do aprendizado em ESD: um estudo experimental. Arq Gastroenterol. 2018,55(3):221-9.

RESUMO - Contexto - A técnica de ESD (Endoscopic Submucosal Dissection) é um procedimento endoscópico de grande complexidade, com alto índice de complicações e dificuldades técnicas. Para superar este problema, muitos centros de treinamento em endoscopia vêm publicando a aplicabilidade dos modelos animais para a aquisição de competência em ESD. Entretanto, a profundidade de ressecção nunca foi utilizada como parâmetro de aprendizagem, o que pode ser um fator relevante a ser ensinado, dado que atingir o plano de dissecção ideal é de suma importância para uma ressecção curativa e na prevenção de complicações intraoperatórias. Objetivo - Analisar o aprendizado em ESD em treinamentos de curta duração através da avaliação da profundidade de submucosa ressecada; e sua associação com complicações. Métodos - Estudo experimental; incluídos 25 endoscopistas com experiência em procedimentos terapêuticos (> 5anos) e 75 peças ressecadas por ESD sendo uma média de três resseções por endoscopista. Os parâmetros de aprendizagem (tempo de ressecção, tamanho, taxa de ressecção em bloco, sangramento, perfuração e análise histológica da camada submucosa) foram prospectivamente avaliados. A percentagem de profundidade de submucosa ressecada foi calculada. Resultados - Todas as ressecções

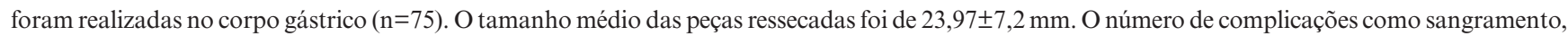
perfuração e morte foram respectivamente, 17 (22,67\%), 3 (4\%) e 0 casos. Na terceira dissecção, tempo médio do procedimento diminuiu de $28,44 \pm 9,73$ para $18,72 \pm 8,81$ minutos $(P<0,001)$. O grupo que teve sangramento durante o procedimento ressecou $37,97 \% \pm 21,13 \%$ da camada submucosa e o grupo sem sangramento ressecou $68,66 \% \pm 23,99 \%$, demonstrando uma associação significante entre a profundidade de dissecção submucosa e a incidência de sangramento $(P<0,001)$. De acordo com a análise de curva ROC, o valor de corte da profundidade de submucosa ressecada para a ocorrência de sangramento é de $61 \%$ (64\% sensibilidade, 94\% especificidade), logo quando o ESD é realizado em uma profundidade maior do que $61 \%$ da camada submucosa o risco de sangramento durante o procedimento diminui (VPP=0,97; IC95\%:0,85-0,99). Conclusão - O modelo de treinamento de curta duração possibilitou um aprendizado da técnica de ESD mostrando uma melhora cognitiva dos alunos já na terceira dissecção. Existe uma associação significativa entre a profundidade de ressecção da submucosa com o risco de sangramento.

DESCRITORES - Ressecção endoscópica de mucosa, educação. Mucosa gástrica. Gastroscopia. Resultado do tratamento.

\section{REFERENCES}

1. Yamazaki K, Saito Y, Fukuzawa M. Endoscopic Dissection of a large laterally spreading tumor in the rectum is a minimally invasive treatment. Clin Gastroent Hepatol. 2008;6:e5-e7

2. Chaves DM, Moura EG, Milhomem D, Arantes VN, Yamazaki K, Maluf F, et al. Initial experience of endoscopic submucosal dissection in Brazil to treat early gastric and esophagheal cancer: a multi-institutional analysis. Arq Gastroenterol. 2013;50:148-52

3. Chaves DM, Maluf Filho F, de Moura EG, Santos ME, Arrais LR, Kawaguti F, Sakai P. Endoscopic submucosal dissection for the treatment of early esophageal and gastric cancer--initial experience of a western center. Clinics (Sao Paulo). 2010;65:377-82

4. Saito I, Tsuji T, Niimi K, Ono S, Kodashima S, Yamamichi N, et al. Complications related to gastric endoscopic submucosal dissection and their managements. Clin Endosc. 2014;47:398-403.

5. Deprez PH, Bergman JJ, Meisner S, Ponchon T, Repici A, Dinis-Ribeiro M, Haringsma J. Current practice with endoscopic submucosal dissection in Europe: position statement from a panel of experts. Endoscopy. 2010;42:853-8.

6. Gotoda T, Friedland S, Hamanaka H, Soetikno R. A learning curve for advanced endoscopic resection. Gastroint Endosc. 2005;62:866-7.

7. Hon SS, Ng SS, Lee JF, LI JC, Lo AW. In vitro porcine training model for colonic endoscopic submucosal dissection: an inexpensive and safe way to acquire a complex endoscopic technique. Surg Endosc. 2010;24:2439-43.

8. Parra-Blanco A, Arnau MR, Nicolas-Perez D, Gimeno-García AZ, González N, Díaz-Acosta JA, et al. Endoscopic submucosal dissection training in pig models in a western country. World J Gastroenterol. 2010;16:2895-900.

9. Figueroa-Barojas P, Sobrino-Cossio S, Hernandez-Guerrero A, Ramírez-Solís ME, Alonso-Lárraga JO, Rodríguez-Brambila V, Álvaro-Villegas J. Endoscopic inanimate biological simulators for training in endoscopic mucosal dissection. Rev Gastroent Mex. 2010;75:380-8.

10. Berr F, Ponchon T, Neureiter D, Kiesslich T, Haringsma J, Kaehler GF, et al Experimental endoscopic submucosal dissection training in a porcine model: learning experience of skilled western endoscopists. Dig Endosc. 2010;23:281-9.

11. Kato M, Gromski M, Jung Y, Chuttani R, Matthes K. The learning curve for endoscopic submucosal dissection in an stablished experimental setting. Surg Endosc. 2013;27:154-61

12. Shimizu M, Nagata K. Pathological evaluation of gastrointestinal endoscopic submucosal dissection materials based on japanese guidelines. World J Gastrointest Endosc. 2012;4:489-99.
13. Toyonaga T, Nishino E, Dozaiku T, Ueda C, Hirooka T. Management to prevent bleeding during endoscopic submucosal dissection using the flush knife for gastric tumors. 2007;19:S14-8. Digestive Endoscopy. 2006;18:S123-7. [Internet]. Wiley Online Library. Available from: https://doi.org/10.1111/j.1443-1661.2007.00740.x

14. Kikuchi D, Lizuka T, Hoteya S, Yamada A, Yamashita S, Domon K, et al. Prospective study about the utility of endoscopic ultrasound for predicting the safety of endoscopic submucosal dissection in early gastric cancer. Gastroenterol Res Pract. 2013;2013:329385.

15. Hosokawa K, Yoshida S. Recent advances in endoscopic mucosal resection for early gastric cancer. Jpn J Cancer Chemother.1998;25:483.

16. Lacerda CAM. Stereological tools in biomedical research. Ann of the Brazillian Academy of Science. 2003;75:469-86.

17. Nyengaard JR, Alwasel SH. Practical stereology of the stomach and intestine Send to Ann Anat. 2014;196:41-7.

18. Schmitz C, Hof PR. Design based sterology in neuroscience. Neuroscience 2005;130:813-31.

19. Howard V, Reed MG. Three-dimensional measurment in microscopy advanced methods. Routledge: Taylor \& Francis, 2005.

20. Mathieu O, Cruz-Orive LM, Hoppeler H, Weibel ER. Measuring error and sampling variation in sterology: comperison of the efficiency o various methods for planar images analysis. J Microsc. 1981;121:75-88.

21. Tsuji Y, Ohata K, Sekiguchi M, Ito T, Chiba H, Gunji T, et al. An effective training system for endoscopic submucosal dissection of gastric neoplasm. Endoscopy. 2001:43:1033-8.

22. Coman RM, Gotoda T, Draganov P. Training in endoscopic submucosal dissection. World J Gastrointest Endosc. 2013;5:369-78.

23. Katenbach T, Soetikno R, Kusano C, Gotoda T. Development of expertise in endoscopic mucosal resection and endoscopic submucosal dissection. Tech Gastrointest Endosc. 2011;13:100-4.

24. Yamamoto S, Uedo N, Ishihara R, Kajimoto N, Ogiyama H, Fukushima Y, et al. Endoscopic Submucosal dissection for early gastric cancer performed by supervised residents: assessment of feasibility and learning curve. Endoscopy. 2009;41:923-8.

25. Yamamoto Y, Fujisaki J, Ishiyama A, Hirasawa T, Igarashi M. Current status of training for endoscopic submucosal dissection for gastric epithelial neoplasm at cancer institute hospital. Dig Endosc. 2012;24(Suppl. 1):148-53.

26. Morabito A, carillio G, Longo R. Systematic treatment of gastric cancer. Critic Rev Oncol Hematol. 2009;70:216-34. 
27. Japanese Gastric Cancer Association. Japanese gastric cancer treatment guidelines 2010. Gastric Cancer. 2011;14:113-23.

28. Flecknell P. Anestesia de animales de laboratorio. Zaragosa: s.n., 1998.

29. Use of experimental animals at John Hopkins University. 2002. [Internet]. [updated 2015 Oct 20]. Available form: http://web.jhu.edu/animalcare/UpdatedBlueBookNoDrugFormulary.pdf.

30. FELASA. Federacion de Asocianciones Europeas de Las Ciencias de Animal de Laboratorio. Recomendaciones para la Eutanasia de los Animales de Experimentacion. [Internet]. [Access 2014 Jun 15]. Available form: http://www.hulp.es/ secal.html.

31. Brunner E, Puri ML. Nonparametric methods in factorial designs. Statistical Papers. 2001;45:1-52.

32. Konietschke F, Bathke AC, Hothorn LA, Brunner E. Testing and estimation of purely nonparametric effects in repeated measures designs. Comput Stat Data Anal. 2010;54:1895-905.

33. Core R, Team. R. A language and environment for statistical computing. R Foundation for Statistical Computing, 2014. [Internet]. [Access 2014 Nov 20] Available form: http://www.R-project.org/.

34. Vazquez-Sequeiros E, Miquel DB, Olcina JR, Martín JA, García M, Lucas DJ, et al. Training model for teaching endoscopic submucosal dissection of gastric tumors. Rev Esp Enferm Dig. 2009;101:546-52.

35. González N, Blanco PA, Gomez MV, Gamba A, Taullard A, Silveira A, et al. Gastric endoscopic submucosal dissection: from animal model to patient. World J Gastroent. 2013;19:8326-34

36. Wagh MS, Waxman I. Animal Models for Endoscopic Simulation. Gastrointest Endosc Clin N Am. 2006;16:451-9.

37. Chaves DM, Gusmon CC, Mestieiri LHM, Moura EGH, Veras MM, Pessorrusso FC, Sakai P. A new technique for performing endoscopic pylorotomy by gastric submucosal tunnel dissection. Surg Lapar Endosc Percutan Tech. 2014;24:e92-4

38. Hondo FY. Estudo experimental comparativo de métodos de dierese tecidual no tratamento endoscópico do diverticulo faringo-esofagico [Tese]. São Paulo: Faculdade de Medicina, Universidade de São Paulo; 2011. 57p.
39. Greenwald D, Cohen J. Evolution of endoscopy simulators and their application. Gastrointest Endosc Clin N Am. 2006;16:386-406.

40. Kim EY, Jeon SW, Kim GH. Chicken soup for teaching and learning ESD. World J Gastroenterol. 2011;17:2618-22.

41. Othman MO, Wallace MB. Endoscopic mucosal resection(EMR) and endoscopic submucosal dissection (ESD) in 2011, a Western perspective. Clin Res Hepatol Gastroenterol. 2011;35:288-94.

42. Berr F, Wagner A, Kiesslich T, Friesenbichler P, Neureiter D. Untutored learning curve to establish endoscopic submucosal dissection on competence level. Digestion. 2014; 89:184-93.

43. Toyonaga T, Man-i M, East JE, Nishino, Ono W, Hirooka T, et al. 1,635 Endoscopic submucosal dissection cases in the esophagus, stomach, and colorectum: complication rates and long-term outcomes. Surg Endosc. 2013; 27:1000-8.

44. Oda I, Gotoda T, Hamanaka H, Eguchi T, Saito D, Matsuda T, et al. Endoscopic submucosal dissection for early gastric cancer: technical feasibility, operation time and complications from a large consecutive series. Digestive Endoscopy. 2005;17:54-8. [Internet]. Wiley Online Library. Available from: https://doi. org/10.1111/j.1443-1661.2005.00459.x

45. Toyonaga T, Nishino E, Hirooka T, Ueda C, Noda K. Intraoperative bleeding in endoscopic submucosal dissection in the stomach and strategy for prevention and treatment. Digestive Endoscopy. 2006;18:S123-7. [Internet]. Wiley Online Library. Available from: https://doi.org/10.1111/j.1443-1661.2006.00645.x

46. Ebi M, Shimura T, Nishiwaki H, Tanaka M, Tsukamoto H, Ozeki K, et al. Management of systolic blood pressure after endoscopic submucosal dissection is crucial for prevention of post-ESD gastric bleeding. Eur J Gastroenterol Hepatol. 2014;26:504-9.

47. Takeuchi T, Ota K, Harada S, Edogawa S, Kojima Y, Tokioka S, et al. The postoperative bleeding rate and its risk factors in patients on antithrombotic therapy who undergo gastric endoscopic submucosal dissection. BMC Gastroenterol. $2013 ; 13: 136-43$ 